\title{
THE KARAKALPAK LEGEND "MAZLUMKHAN SULU” AND ITS SUBJECT PARALLELS IN THE KHOREZM FOLKLORE
}

\author{
Bekimbetov A.M. \\ Doctor of Philological Sciences (PhD), \\ Junior Researcher, \\ Karakalpak Scientific Research Institute of Humanities, \\ Karakalpak Branch of the Academy of Sciences of the Republic of Uzbekistan, \\ Nukus. Republic of Karakalpakstan, \\ Uzbekistan
}

Article DOI: https://doi.org/10.36713/epra5895

\begin{abstract}
The article is devoted to one of the little-studied themes of Karakalpak folklore - the problem of migration of folklore scenes. The author of the article, based on an analysis of folklore material, attempted to link the history of the origin and formation of the legend of Mazlumkhan Sulu with the parallels found in Khorezmian folklore, as well as to identify the historical and traditionally epic prerequisites for the migration of the plot to Karakalpak folklore.
\end{abstract}

KEY WORDS: legend, plot, motive, migration, parallels, folklore, tradition, source, epic.

\section{INTRODUCTION}

The Khorezm oasis, as one of the centers of the ancient civilization, played a significant role in the cultural life of the peoples inhabiting it, including Karakalpak, which for long historical periods was in close economic and cultural relationship with the peoples of Khorezm. Traces of this relationship are especially clearly seen in Karakalpak folklore. The composition of the Karakalpak folk legends, as well as other Turkic peoples, was enriched by borrowing, both from neighboring peoples, and their own autochthonous ones. Plots of Khorezm folklore had a great influence on the design of individual Karakalpak legends.

\section{DISCUSSION}

One of the most interesting and unique of them is the plot "princess and builder slave", which left a deep and bright mark in enriching the subject of Karakalpak folk legends.

The toponymic legend with the plot "Mistress and a slave builder" was timed to the mausoleum of Mazlumkhan Sulu, a religious building located in the territory of the Khodzheli district of the Republic of Karakalpakstan. This religious building to this day is a place of pilgrimage for local residents. The construction of the mausoleum, according to experts, dates back to the end of the XII - the beginning of the XIV centuries. [1, p. 569-585]. The first studies of this monument were made by A.Yu. Yakubovsky in 1928-1929, then repeated studies were carried out in the interval 19401980. archaeologists Yu. V. Knozorov, VN Yagodin, and G. Chojaniyazov, who focused their attention also on the content of the legend. One of the first records of the legend was made by the famous Karakalpak ethnographer H. Yesbergenov. In 1964, he recorded with the informant, the text of the legend, however, this text was not given in the article he prepared. According to legend, Mazlumkhan Sulu was the daughter of a ruler, to whom the peoples of India, Front and Central Asia were subordinate. The territory of Khorezm was the lot of Mazlumkhan Sulu. One of the slaves, who was a builder from India, fell in love with Mazlumkhan Sulu. Mazlumhan also fell in love with a young man. However, knowing that her father would not agree to give her for a slave, and also to check the truth of his feelings, she told him to build a barn (palace), which should not be like all other existing ones. A slave built this palace for her. Seeing the palace, she loved him even more. Knowing that during their earthly life 
they would never unite, Mazlumkhan Sulu told him: "If you really love me, then throw yourself from the roof of this palace." The slave obeyed and died. Following him, Mazlumkhan herself rushes and dies. Both of them were buried in the palace, which became a mausoleum [2, p. 77]. Numerous versions of the legends that existed among the people, the fact of the presence of a gravestone with fragments of a poem, gave thought to many researchers. A fragment of the poem was translated by experts, and on its basis $\mathrm{H}$. Yesbergenov tried to recreate the real story about Mazlumkhan Sulu, which formed the basis of the legend.

On the basis of data collected from the local population, the palace, now functioning as the mausoleum of Mazlumkhan Sulu, was built in the period when India and Khorezm were ruled by a single ruler. According to the ethnographer, the construction of the palace dates back to the reign of Mahmoud Ghazni (998-1030), whose power stretched from the borders of northern India to the southern shores of the Caspian Sea, including areas of present-day Afghanistan and northeastern Iran. Ghaznavid state played a large role in the fate of Iran and Central Asia, in particular Maverannahr. During his reign, Mahmud of Ghazni made seventeen trips to Punjab, Kashmir and other areas of northern India. On one of his trips, Mahmud took out 20 million dirhams, 57 thousand slaves and 350 elephants from the city of Kanauja [3, p. 359]. It can be assumed, the scientist writes, - that some of these slaves participated in various constructions in Khorezm, including the construction of the Mazlumkhan Sulu mausoleum [4, p. 69]. The ethnographer, based on the above data, relates the construction of the mausoleum to the 9th - 11th centuries. Relying on another version of the legend and the content of the poem from the tombstone, translated by A. Nekrasov, H. Esbergenov tries to connect Mazlumkhan Sulu with a cult widespread in Central Asia since antiquity - the cult of the Holy Virgin. As proof of his conclusion, he cites the text of the above-mentioned poem, which reads:

\section{Oh my close ...}

Be proud of me!

Do not think that I am unhappy in the cell of the dust.

Know that I am an approximate sanctuary of holiness.

And consider me to be one of the hermits of paradise.

Paradise servant $[4$, p. 66].

As can be seen from the content of the poetic lines, it is clearly enough noted that Mazlumkhan Sulu died of a virgin. According to the ideas of many Turkic-speaking (Turkic) peoples, including Karakalpaks, innocent girls after death must go to heaven. The conclusion of the researcher, to some extent coincides with the opinion of the orientalist A. Nekrasov, which he mentions several times in his article. The orientalist drew attention to the word "mhshate", which according to him in India is called a matchmaker, and in Persia - women, whose duties include combing the bride's hair before a wedding, decorating her [5, p. 584]. Apparently, Mazlumkhan Sulu before the burial was removed as a bride. The custom of burial in wedding decoration was in ancient times widespread among many nations of the world. Its origins are connected with the cult of the Eternal Virgin $[4$, p. 67]. The tradition of the Karakalpaks on the special status of girls in society, which has survived to this day, served to strengthen the ethnographer's conclusion, to some extent.

After the discovery of a gravestone in 1971, an ethnographic expedition in the area of Keten Kala, located not far from the Mazlumkhan Sulu mausoleum, and after his research by H. Esbergenov, new facts are discovered concerning this mausoleum. In this regard, in 1976, an article appeared in the press devoted to the content of the poetic text similar to that of Mazlumkhan, from a gravestone monument from Keten Kala [2, p. 77]. The poetic texts of both gravestones belong to the representatives of the Mu'tazilite Sufi sense. Sufism, which arose much earlier in the VIII century. on the territory of Iraq and Syria, to the XI- XII centuries. widespread in Central Asia. In the lower reaches of the Amu Darya, one of the centers of Sufism was undoubtedly the cult construction of Mazlumkhan Sulu. In addition to the eponymous mausoleum with the grave of the martyr (the word "mazlum" translates as "martyr") [6, p. 86] Calender Khan, the hostel of dervishes and the ruins of the Erezhep Halfa mosque, one of the devotees of the Dervish Order, remained on this hill. All the findings of the researcher lead us to the fact that the prototype of the legend, that is, Mazlumkhan Sulu, buried in the mausoleum that bears her name, is a representative of Sufism. As evidence, he cites another version of the legend, which is supported by data obtained from informants, according to which Mazlumkhan Sulu led an ascetic lifestyle, and spent her life alone [4, p. 69]. This ethnographic survey of Mazlumkhan Sulu, was the key in determining the origins of the formation of the legend and its variants.

A comprehensive study of the formation of legends on a regional scale, which includes the folklore of the peoples of Khorezm and Karakalpakia, in our opinion, gave us significant conclusions about the traditional ways of its design as a legend. The Khorezm variant of the legend is known to us from the work of G. P. Snesarev, who studied the religious cults of the Khorezm region [7, p. 160-161]. The scientist wrote down the text of the legend with Sheikh Mazar Divanai Burkh in KunyaUrgench, but the name of the informant is not mentioned in the work. For clarity, in a comparative study with the text of the legend of Mazlumkhan Sulu, we give it in its most complete form. "When 
Tyuryabek was building, the building of the present mausoleum Sheikh Sheref unexpectedly drove up to the construction site on the donkey of some unknown sofa, and addressed the owner with the strange question:“ Will you sell me this palace, Tyuryabek? ". Having understood the joke, the beautiful woman answered: "Well, but only this whole building is in gold!". Divan, and this was someone other than Saint Sheikh Sheref, climbed the dome of the mausoleum and shook his right sleeve over the hole in the ceiling. Gold poured from the sleeve and rained down until the whole tomb filled them. "Release this mazar from gold now," said the Sheikh, and Tyuryabek carried out his order. "Why did I just sell the palace," Tyuryabek doubted, "No one will remember me now, since I voluntarily lost this building!" In tears, she fell asleep and saw in a dream that wonderful building that is in paradise. Awakened from sleep, she personally drafted his plan and ordered the construction to begin. Masters built it for seven years.

With builders Tyuryabek paid off with gold, received by it from the Sheikh. Only one master, a young slave builder Kul Gardan, flatly refused to take the money, and demanded the love of Tyuryab. "If you rush from the height of this beautiful portal, I will believe that you love me," the beauty replied. Kul Gardan did not hesitate to prove his love and died. She put the head of the deceased in her lap and said: "We will see you in the next world." She buried the master near the building he had constructed "[7, p. 160-161]. According to another version of the plot, which was also recorded by G. P. Snesarev, Tyuryabek herself chooses death $[8, \mathrm{p}$. 114]. The similarity of the content of the text of the legend obviously claims to be variant with the legend of Mazlumkhan Sulu, with the exception of having a motive in it related to another character in the person of Sheikh Sheref. In both legends, the main characters of the plot "princess and builder slave" appear, and it remains to be clarified which of them was the main source of variation of the plot and design of another legend. Based on historical sources, we will try to establish it. G.P. Snesarev himself, ignoring the legend of Mazlumkhan Sulu, turns his attention to another legend with the traditional plot "princess and builder slave", that is, the legend associated with Bibi-Khanym, where Timur's beautiful wife appears and a young slave in love with her, demanding in payment for his work a kiss hostess. "We take courage," writes the researcher, "that the origins of the Samarkand legend about BibiKhanym should be sought in Khorezm: the beginning was laid in Kunya-Urgench by the legend about Tyuribek Khanym and the master Kul Gardan. We know how easily the legendary plots cover the distance, but for this case there were historically quite real prerequisites for such a "movement" of the plot " $[7$, p. 166].
As is known, the construction of the Bibi Khanim mosque in Samarkand was carried out after the military campaigns of Timur in Khorezm. Urgench was conquered. Many masters as prisoners were transported to Samarkand. It is known that the masters of Khorezm in Shakhrisabz built the Aksaray Palace, the residence of Timur. Probably, they were also employed in the construction of other structures of Timurov time, in particular, the Bibi khanim mosque. "It is possible," G. Snesarev concludes, "that it was with captive Urgench masters that they came to Samarkand and the plot of the Khorezm legend [7, p. 167].

There are also historical prerequisites for the design of the plot "The Princess and the Builder of a Slave" to the legend of Mazlumkhan Sulu, the source of which, in our opinion, is the legend of Tyuryabek Khanym. Historical Tyuryabek lived in the first half of the 14th century, and was the wife of the Golden Horde governor Kutlug Timur [9, p. 169]. The capital of the governorship then was Kunya Urgench. This was the period of the new economic and cultural upturn of Khorezm, after the devastating raids of Genghis Khan's troops. Kutlug Timur, the governor of Khorezm was an approximate of the Golden Horde Khan Uzbek; besides, he was related to him, and contributed to his accession to the khan's throne. Kutlug was married to the daughter of Uzbek Khan Tyuryabek Khanum. Khorezm, even before the Mongol invasion, was the center of the Islamization of the steppe and semi-settled people, and those tribes that moved to these places together with the Genghisides. The significance of Khorezm in the Islamization of the Golden Horde itself was great. A significant role in this was played by Kutlug Timur and his spouse. As B.D. Grekov and A.Y. Yakubovsky noted: "Kutlug Timur, giving support to Uzbek, demanded the last decisive turn towards the adoption of Islam" [10, p. 266-267]. In Khorezm, near Kunya Urgench, stands a grand minaret built by Kutlug Timur. His wife Tyuryabek, in turn, built a mosque in Urgench. Many spouses have done for the Sufi communities. Kutlug built two khanaks and established waqfs for the benefit of each of them, including extensive land and canals [9, p. 169-170]. It means that the real Tyuryabek, the wife of the governor of Khorezm, undoubtedly labored on the path of the builder of religious institutions. The popularity of this woman - the builder, patron of the arts, the patroness of Islam and its institutions, made her a legendary person during her lifetime and subsequent periods of the historical life of the peoples of Khorezm.

There is much in common in the legends about Tyuryabek Khanim and Mazlumkhan Sulu both of them are representatives of the ruling stratum, the initiators of the construction of the palace mentioned in the legends are in the same position and slaves are builders in love with them. Proceeding 
from this, and based on the specific methods of folk tradition in varying the texts of legends, we can conclude that we have two links to directly transmit the plot of the "princess and slave builder" from the Khorezmians to the Karakalpaks, that is, the legend of Tyuryabek xanim, with some changes, made by time, is dedicated to the mausoleum of Mazlumkhan Sulu. Tyuryabek Khanum was replaced by Mazlumkhan Sulu, and the young architect Kul Gardan from the Indian builder was replaced by a slave. The archaeologist G. Khojaniyazov, who studied the mausoleum in 1987-1990, notes that the monument in the XII-XIII centuries. used as a khanaka (hostel for dervishes), later to the XIV century. his premises were set aside for burial, and he was turned into a mausoleum [11, p. 20]. From this it can be assumed that the buried, young girl in the mausoleum is the prototype Mazlumkhan Sulu, according to legend, found shelter here not earlier than the end of the XIV century, and a gravestone monument with epigraphy was built by representatives of Sufism. In addition, among the Karakalpaks and Khorezmians there are other similar content legends about Tyuryak khanim and Mazlumkhan Sulu, where young women after the death of their loved ones choose an ascetic lifestyle, devoting themselves to serving God, and spend the rest of their lives alone, which is inherent in Sufism ideology. Based on the analysis of ways of variation of the plot "Mistress and slave builder" and the above conclusions of ethnographer Kh. Yesbergenov about the involvement of Mazlumkhan Sulu's personality in the Sufi current, it can be concluded that the burial of a young woman in whose honor this mausoleum was named was one of the objects of popularization ideology of sufism.

The legends of Tyuryabek Khanym and Mazlumkhan Sulu are not the only links in the migration chain of the "princess and builder slave" plot. The origins of the formation of legends in our research go back to the legend of Farhad, timed to the remnants of the ancient fortress of Devkala (the city of the giant), which has the name Sulayman Kala among the people. The famous Uzbek folklorist K. Imamov mentions the legend in his work. According to legend, the fortress of Dev Kala was built by a giant named Farhad. He falls in love with a daughter of Khorezmshah named Shirin, and sends his matchmakers to her father. He did not want to give his daughter for him, the Khorezm Khan, to ask the sorceress (zhodugar) for advice. She advises Khan to entrust the maiden with an impossible task - to build a fortress in the center of a deserted desert. Farhad proceeds to carry out the task: he drags stones from distant mountains on his shoulders and proceeds to the construction of a fortress. When the construction of the fortress comes to an end, frightened by this circumstance, the Khorezm Khan again calls the witch for help. She tells Khan to slaughter 9,000 camels, as many lambs and calves. Voices, animals that have lost their young reach the fortress that Farhad is building. Surprised, he asks the witch: "Where does this heartbreaking cry come from?" To which the evil witch replies: "Princess Shirin just died and everyone grieves for her." Having lost himself from the sudden news of death, and who did not want to live without his beloved maidens, Farhad takes a large stone, and, gathering all his strength, hurls him upwards. The falling stone falls directly on him. Hearing about the event, the princess rushes to the scene and finds Farhad dead. Unwilling to live without her beloved, Shirin kills herself with a knife [12, p. 69].

Another version of the legend confined to the Chilpyk hill associated with the maiden is mentioned by the Hungarian traveler Arminius Vamberi, who wrote it down during his trip to Central Asia. This legend is widespread among the peoples of Khorezm and Karakalpakstan. She tells that in ancient times it was a strong fortress, and that a certain princess, who fell in love with her father's slave, found refuge here; fearing the revenge of the infuriated father, she fled here with her lover. To get water, the slave had to drill a mountain all the way to the river; the underground passage still exists $[13, p$. 113-114]. Judging by the content of the legend recorded by Vambery, it is somewhat abbreviated. In another, full version of this legend, recorded by the author of this article from informant Ulbiyke (87 years old, resident of Nukus), the image of a virgin appears in it [14]. In the full version of the legend, fearing revenge on the father of the princess, nobody wanted to shelter lovers in their fortresses. Only one virgin, the owner of the fortress, on the hill Chilpyk, dares to do it, and protects lovers from their enemies.

In general, the virgin is a fairly widespread character of the legends of the Khorezm region, Karakalpak folklore is also replete with images, and he appears mainly in toponymic legends, telling about the origin or construction of some kind of fortress or artificially constructed hill, which served, according to researchers, the object of body burial the departed. This is explained by the fact that the Khorezmian version of the image of a virgin is quite clearly degraded, that is, it has one characteristic feature that is interesting in terms of genetic relationships with the ancient Iranian pandemonium. Here virgins are primarily builders of cities and fortresses [8, p. 62]. Apparently, the existence of the image of the virgin in the Khorezm and Karakalpak legend has already created a fertile ground for its further transformation into the images of the builders of slaves; first in the legend of Tyurabek Khanim in Quli Gardan and after, the legend of Mahalumkhan Sulu being analyzed by us as an Indian slave.

Our analysis of the legends (about Mazlumkhan sulu, Tyurabek Khanim, Farhad), as links of one migration chain, formed on the basis of 
the plot "princess and builder slave", can disprove the opinion that the plot of the legend of Mazlumkhan Sulu arose independently among the Karakalpaks. In favor of our conclusion about its variation with the legend of Turebek Khanym, we will try to substantiate the following data. According to the stories of the archeologist G. Hochaniyazov, who participated in the study of the mausoleum, during the opening of the graves, according to popular data, to the prototypes of the legend of Mazlumkhan Sulu and the builder of the slave, the remains of the bones of a young woman aged about 18-20 years and a young man 25-30 years old, whose age is accurately shown in the legend. If we assume that the case really took place in reality, and the mausoleum erected in honor of the lovers became the reason for the creation of the legend about them, then a number of objective reasons can refute this. First, the structure erected above the grave is not a palace, but built as a khanaka - a hostel for representatives of the servants of Sufism. The burial of the bodies of the departed in these premises began somewhat later. Secondly, Mazlumkhan Sulu, the prototype of the legend, could not be the daughter of Khan, since the center of the governorship assumed in the legend was at that time in Kunya Urgench. Most likely, Mazlumkhan Sulu belonged to the family of a noble and wealthy representative of the local nobility, only a similar category of people could afford to be buried in such a luxurious building. Thirdly, if we take into account the opinions of scientists that the burial refers to a period not earlier than the 14th century, when the peoples of Khorezm, including the Karakalpaks, were completely Muslim, their way of life. They mainly obeyed the instructions of the Koran, in which suicide was a terrible sin, and the glorification of such cases would not be supported by the traditional morality of the society of that time. Most likely, it would be condemned. The situation is different with the folk epic tradition: "rumors" and "interpretations" about the tragedy of lovers were not "defended" in order to take shape into a legend. Over time, this echo of reality was replaced by the legend of Tyuryabek Khanum, already finished and preserved in folk tradition, only by changing names and geographical location.

\section{CONCLUSION}

Summing up our analysis of the borrowing of the plot of the legend of Mazlumkhan Sulu from Khorezmian folklore, we emphasize that the plot of this legend is not an exceptional case in the chain of borrowings. The Karakalpak people with Khorezm are linked by centuries-old historical, cultural and socio-economic relations that have left their mark on folk art, the study of which can reveal many facts of borrowing in Karakalpak folklore.

\section{REFERENCES}

1. Yakubovsky A.Yu. The ancient settlement Mizdakhkan // Notes of the College of Orientalists at the Asian Museum of the USSR Academy of Sciences, Vol.V. L., 1930. 585 with.

2. Esbergenov. H. Nadmogilnye stones from Ketenkaly and Mazlumkhan Sulu with inscriptions of the mutalist sense // Bulletin of the Karakalpak Branch of the Academy of Sciences of the UzSSR. Nukus, 1976. № 2. 100 p.

3. History of the Uzbek SSR. T. I. Tashkent, 1967. $359 \mathrm{p}$.

4. Ethnic history and traditional culture of the peoples of Central Asia and Kazakhstan. - Nukus. 1989. $272 p$.

5. Nekrasov A. Inscriptions on the tombstones of the Mazlum Sulu mausoleum in Mizdahkan. Notes of the College of Orientalists at the Asian Museum of the USSR Academy of Sciences, T. V. L., Publishing House of the Academy of Sciences of the USSR, 1930, p. 588.

6. Knozorov V. Mazar Shamun Nabi. "Soviet Ethnography”, 1949, No. 2, p. 242.

7. Snesarev G.P. Khorezm legends as a source on the history of religious cults of Central Asia. M. 1983. with. 212.

8. Snesarev G.P. Relics of pre-Muslim beliefs and rituals among the Uzbeks of Khorezm. M. 1969. p. 336.

9. Gulyamov Ya.G. The history of the irrigation of Khorezm from ancient times to the present day. Tashkent: Publishing House of the Academy of Sciences of the Uzbek SSR. 1957. with. 313.

10. Greek B.D., Yakubovsky A.Yu. The Golden Horde and its fall. with. 505.

11. Chozhaniyazov G. Yusupov O. The holy places of Karakalpakstan. Nukus 1994. p. 107.

12. Imomov K. Uzbek Khalk prozass. Tashkent. 1981. p. 102.

13. Armenia Vamberi. Travel in Central Asia. M. 2003. p. 193

14. Field records by A. Bekimbetova. Notebook number 2. INV 183830 